\title{
Why Wield Constitutions to Arrest International Law ${ }^{1}$
}

\author{
Prabhakar Singh
}

A constitution's seductive potential cannot be ignored even in international law. Though partisan in character, a constitutional lens, inter alia, is increasingly used to see international law today. While European lawyers interpret the Kadi judgement of the Court of Justice of the European Union (ECJ) as pluralist - a case of embracing monism upside-down - a developing country observer clearly sees Kadi as dualist. American scholars envisage international law subordinate to the United States' constitution. From a studied monism Europe has moved to pluralism while the U.S. has always been dualist. In the post-colonial era, many developing and least developed countries (Third World) have established a successful constitu-

1 This essay is dedicated to the life and work of late Professor R. P. Anand (19332011) who will always inspire generations of international lawyers to a just world order.

2 President's Graduate Fellow, and Associate, Centre for International Law, Faculty of Law, National University of Singapore; LL.M. (University of Barcelona), Spain; B.A. LL.B. (Hons.) (National Law Institute University), Bhopal, India. I began writing this article while visiting the European Court of Justice, Luxembourg in May 2007. In January 2008, I presented the first draft at the Conference of the Toronto Group for the Study of International, Transnational, and Comparative Law, Toronto University. Quislex Legal Services Pvt. Ltd. was kind enough to fund my travel to both Luxembourg and Toronto. On the grant of funds from the Graduate School of International Development, Nagoya University, Japan I was able to visit Japan to research and present a subsequent draft of this paper. Comments from Cheryl Saunders, Shilpi Bhattacharya, Raeesa Vakil, Charles Maddox, Pasha Hsieh and Hee Eun Lee helped me improve the article immensely. However, errors are all mine. <prabhakarsingh.adv@gmail.com>. 
tional democracy. Little surprise then, a new found constitutional confidence is colouring such countries' international advocacy. In India - QRs, India drove the separation of power argument that New Zealand had made in the Rainbow Warrior case a step further. However constitutionalism, as an ideology, remains, as is often the case, an inconclusive question for an eternally observing Third World. This article discusses the rise of constitutionalism in international law and the Third World's possible responses.

\section{INTRODUCTION}

After the assault on international law in the war on terror, academics are nursing international law's injuries through constitutionalism. ${ }^{3}$ The

3 In the post 9/11 world, constitutional debates promise to fill the chasm between international security and international law. Mattias Kumm, The Legitimacy of International Law: A Constitutionalist Framework of Analysis, 15 EUR. J. INT'L L. 907-931 (2004). Klabbers thinks it is tough to reach a definition of this term. Jan Klabbers, Constitutionalism lite, 1 InT'L Org. L. Rev. 1 (2004). This question has descriptive, conceptual and normative components. See Jeffrey Dunoff \& Joel Trachtman, Ruling The World? Constitutionalism, International Law and Global Governance, EJIL: Debate! (Thursday, Dec. 10, 2009). For Bogdandy, constitutionalism is "striving for a global legal community that frames and directs political power in the light of common values and a common good." Armin von Bogdandy, Constitutionalism in International Law: Comment on a Proposal from Germany, 47 HARv. INT'L L.J. 223 (2006). Nonetheless, its timing and prominence, according to Dunoff, give rise to constitutional debates "reflecting disciplinary anxieties that have been heightened by recent geopolitical developments." Jeffery Dunoff, Constitutional Conceits: the WTO's Constitution and the Discipline of International Law, 17 EUR. J. INT'L L. 647 (2006). Cho contends that "constitutional adjudication is self-legitimizing to the extent that such adjudication communicates with the domestic legal system via various forms of internalization, be it a judicial accommodation, as regards the Charming Betsy doctrine, or a policy change at the executive level." After all, Cho argues, compliance leads to legitimacy insomuch as legitimacy renders compliance pull. Sungjoon Cho, Global Constitutional Process, 31 U. Penn. J. InT'L L. 621, 676 (2010). Dunoff sees no constitutional chromosomes whatsoever in the body of international law, Dunoff, ibid, at 64775; Bogdandy sees them very clearly. Armin von Bogdandy, Law and politics in the WTO: Strategies to Cope with a Deficient Relationship, 5 Max PlancK YEARBOок U.N. L. 609, 614 (2001). Astonishingly, such opposite understandings 
story of constitutionalism began with the advocacy that the United Nations (UN) should be seen as the constitution of the world. ${ }^{4}$ The debate has moved further since then. International institutions are now seen as lawmakers. ${ }^{5}$ Article $38(1)(d)$ of the Statute establishing the International Court of Justice - the teachings of the most highly qualified publicists of the various nations - allows lawyers to nurse international law; albeit such works remain only subsidiary sources of international law. Be that as it may, in a purely legal critique, Sornarajah establishes that international law is often kidnapped by powerful nations, inter alia, through academic writings, which sometimes even trump the sovereign wishes of weaker nations. ${ }^{6}$ Since within the power-based understanding of international law, publicists' views often reflect the interest of their nations, scholarly publi-

come up while analysing the same legal instrument — the WTO agreement. While analysing international law vis-à-vis EC law, Koskenniemi, far removed from both Dunoff and Bogdandy, sees constitutionalism as a "mindset." See generally, Martti Koskenniemi, Constitutionalism as Mindset: Reflections on Kantian Themes about International Law and Globalization, 8 THEORETICAL INQUIRIES IN L. 9-36 (2007). See, e.g., Prabhakar Singh, International Law as Intimate Enemy, 14 Or. Rev. INT'L L. 377 (2012) for a new lens to see international law.

4 Bardo Fassbender, The United Nations Charter As Constitution of the International Community, 36 Colum. J. Transnt'L L. 531-619 (1998); Erika De Wet, International Constitutional Order, 55 InT'L \& CoMP. L. Q. 51-76 (2006).

5 Armin von Bogdandy \& Ingo Venzke, Beyond Dispute: International Judicial Institutions as Lawmakers, 12 GERMAN L. J. 979-1004 (2011).

6 "A series of arbitral awards, followed by confirmatory writings of the so-called "highly qualified publicists," all of them coming from the so-called "civilised legal systems," held that such a contract was akin to a treaty in that responsibility of the state followed the event of the breach of the contract and failure to amend the breach. The use of awards of tribunals and the writings of "highly qualified publicists," often mercenary participants in the litigation writing up their opinions or briefs as articles in "learned" journals, resulted in the creation of an international law in the area. The practice still continues. The members of the so called "arbitration fraternity" elevate each other in status, cite each other's views and create law on the basis that they are "highly qualified publicists." It is hypocritical that no text on international law adverts to this practice of lawmaking for so many states and peoples by so few in an age in which there is much talk of democratic legitimacy." See M. Sornarajah, Power And Justice: Third World Resistance In International Law, 10 Singapore YB INT'L L. 19, 31 (2006). 
cations have much to add to the sources of international law. Therefore, if European lawyers, highly qualified publicists, project a constitutional or any other view of international law, it is worth a discussion from a Third World angle. Consequently, three observations are in order:.

(1) There is a burgeoning European trend to see governance through a constitutional lens. ${ }^{7}$ Regardless, American scholarship regularly rejects this. ${ }^{8}$

(2) Even against a sharp criticism, the division of our planet into three worlds remains a useful categorisation to study behavioural internationalism of the states. ${ }^{9}$

(3) The project of international law is increasingly seeking refuge in constitutionalism for its survival.

How does one assess constitutional developments in international law in the context of global constitutionalism today? ${ }^{10}$ In the Paquete Habana case, the U.S. Supreme Court identified "Japan as a last member of the civilized nations whose legal customs were allowed to be taken into comparative judicial account. ${ }^{11}$ "Since then countries like India have developed robust constitutional democracy. Nonetheless due to colonialism's effect on the non-Western world, anything European is reliably constitutional and easily international today. It is this decidedly European nature of the constitutional argument that displeases the Americans and Third worlders. Europe gave sovereignty to the world, and when the Third World, due in large part to colonialism, has accepted the idea of sovereignty, Europe has

7 Bogdandy, supra note 3, at 223.

8 Paul Stephan, US Constitutionalism and International Law: What the Multilateralist Move Leaves Out, 2 J. InT'L Criminal Justice 11-16 (2004).

9 B.S. Chimni, Third World Approaches to International Law: A Manifesto, 8 InT'L Смту. L. Rev. 3-27, (2006)

10 Jiunn-Rong Yeh \& Wen-Chen Chang, The Emergence of East Asian Constitutionalism: Features in Comparison, 59 Aм. J. Coмp. L. 805, 806 (2011).

11 The Paquete Habana, 175 U.S. 677 (1900). The idea of a civilized state and its customs is now well established in international law. See Statute of the International Court of Justice, Article 38(1)(c), "the general principles of law recognized by civilized nations," available at http://www.icj-cij.org/documents/ index.php?p1 $=4 \& \mathrm{p} 2=2 \& \mathrm{p} 3=0$. 
moved to a post-national position. European Union (EU) is thus a source of constitutional interpretation of international law through its highly qualified publicists as the article 38 (1) (d) of the Statute of the International Court of Justice stipulates. As such, it is argued that from a third world perspective, the rise of constitutionalism in international law looks suspect and thus worthy of investigation. This article is a humble step in that direction.

\section{FROM EUROPEAN TO WTO CONSTITUTIONALISM}

Though consisting mostly of Europeans, there is a growing school of constitutionalists. ${ }^{12}$ Constitutionalism is a crystallization of domestic institutional virtues for reworking internationalism. However unanimity over the true definition of constitutionalism continue to elude scholars. ${ }^{13}$ International legal scholarship harbours very divergent, sometimes conflicting, notions of constitutionalist debates.

For some, constitutionalism is a medicine to the fragmentation of international law. ${ }^{14}$ Notably, harking back to constitutionalism gives Europe a distinctive advantage; it breaches international law yet it can defend itself as champion of individual internationalism by claiming to protect the human rights of member country citizens. Thus even if the EU's constitutional norms trump universal international law, it nonetheless crafts a state practice which is applicable among twenty-seven plus EU member states. This fashions an unprecedented situation within international law, a model

12 Bogdandy, Ackerman, de Wet, de Búrca, Klabbers, Koskenniemi, Walker, Peters, Maduro, Petersmann, Kumm, Trachtman, Rosenfeld and Suo, inter alia, are some of the constitutional and pluralist scholars. See, e.g., Ming-Sung Kuo, The End of Constitutionalism As We Know It? Boundaries and the State of Global Constitutional (Dis)Ordering, 3(1) Transnat'L Legal Theory 329-369 (2010); See Jeffrey Dunoff \& Joel Trachtman, The Lotus Eaters, 6, EJIL Analysis /EJIL Debate! (Jul 16, 2010).

13 Bruce Ackerman, The Rise of World Constitutionalism 83 VA. L. REv. 771797 (1997); Bogdandy, Proposal from Germany, supra note 3; Anne peters, Compensatory Constitutionalism: The Function and Potential of Fundamental International Norms and Structures 19 LEIDEN J. INT'L L. 579 (2006).

14 See generally, Koskenniemi, supra note 3, at 9-36. 
that cannot be imitated by a Third World sovereign and thus does not add usefully to the growth of customary international law or state practice.

The build-up of constitutional and human rights courts the world over further aids to the constitutional advocacy within international law. ${ }^{15}$ Inter alia, some of these courts are the ECJ, ${ }^{16}$ Inter-American Court of Human Rights, ${ }^{17}$ European Court of Human Rights, ${ }^{18}$ and African Court on Human and Peoples' Rights. ${ }^{19}$ John Jackson, Ernst-Ulrich Petersmann and Deborah

15 International Criminal Court is not part of the UN system. See ICC: About the Court, 2, available on http://www.icc-cpi.int/Menus/ICC/About+the+Court/. It reads "governed by the Rome Statute, is the first permanent, treaty based, international criminal court established to help end impunity for the perpetrators of the most serious crimes of concern to the international community." $I d$., at 1.

16 The ECJ was established in 1952. See, http://curia.europa.eu/jcms/jcms/Jo2_6999/. The ECJ was set up under the Treaty of Paris (1951) to implement the legal framework of the European Coal and Steel Community (ECSC). When the European Community was set up under the Treaty of Rome (1957), the ECJ became its court. When the European Union was created under the Maastricht Treaty (1992), the ECJ's powers were again expanded to cover the broader legal remit of the EU. The Lisbon Treaty (2007) again extended the ECJ's remit to include, among other areas, Justice and Home Affairs, as well as renaming the courts the "Court of Justice of the European Union." The number of cases sent to the ECJ has grown dramatically since the institution was established. The Court of First Instance was renamed the "General Court" in the Lisbon Treaty. In addition to this, the Civil Service Tribunal was set up in 2005 to adjudicate in disputes between the EU and its civil service. All three courts are based in Luxembourg. See ECJ, available at http://www.civitas.org.uk/eufacts/FSINST/IN5.htm.

17 The Inter-American Court of Human Rights is located in San José, Costa Rica. The inter-American human rights system was born with the adoption of the American Declaration of the Rights and Duties of Man in Bogotá, Colombia in April of 1948 See http://www.cidh.oas.org/what.htm.

18 See ECtHR, available at http://www.echr.coe.int/echr/homepage_EN. The ECtHR recently brought out Statistics on judgments by State to further concretize its importance. See The Council of Europe, Judgments by State: Statistics 1959-2010, available at, http://www.echr.coe.int/NR/rdonlyres/E6B7605E-6D3C-4E85A84D-6DD59C69F212/0/Graphique_violation_en.pdf.

19 See African Court on Human and Peoples' Rights, Sept. 22, 2011, available at http://www.african-court.org/en/. However one can always contest the effectiveness of international courts. See George M. Wachira, African Court on 
Cass are the chief architects of a constitutional view of international trade law. ${ }^{20}$ Their advocacy has been the basis for new scholars to either find or oppose a constitutional interpretation of the WTO law. ${ }^{21}$

[Sungjoon Cho] identifies a nascent phenomenon of "global constitutional lawmaking" in recent "WTO" jurisprudence that struck down a certain calculative methodology ("zeroing”) in the anti-dumping area ... [Cho] interprets the Appellate Body's uncharacteristic anti-zeroing hermeneutics, which departs from a traditional treaty interpretation under the Vienna Convention on the Law of Treaties and the past pro-zeroing under the General Agreement on Tariffs and Trade ("GATT") case law, as a "constitutional" turn of the WTO ... [Cho] argues that a positivist, inter-governmental mode of thinking, as is prevalent in other international organizations such as the United Nations, cannot fully expound this phenomenon. ${ }^{22}$

Furthermore, Kill believes that the WTO Panel's Report in Mexico-Measures Affecting Telecommunications Services ${ }^{23}$ dished out a possibility of a right-based constitutionalism as a "theory that comes complete not only with an ideology, but with a specific model of a judiciary as accomplice in achieving its ideological goals." ${ }^{24}$ There is definitely a methodical tact in the changing hermeneutics of the WTO - like any other international court there is a discursive burden on the WTO to keep its irrelevance at bay. A

Human and Peoples' Rights: Ten years on and still no justice, Report: Minority Rights Group International (2008), available at, http://www.unhcr.org/refworld/ pdfid/48e4763c2.pdf.

20 See Ernst-Ulrich Petersmann, Theories of Justice, Human Rights and the Constitution of International Markets, 37 Loyola L. Rev. 2004, 407-460; Petersmann, Human Rights, Constitutionalism and the WTO: Challenges for WTO Jurisprudence and Civil Society, 19 LeIden J. Int'L L. 633-667 (2006); Deborah Cass, The Constitutionalization of the World Trade Organization (2005).

21 Joel P. Trachtman, The Constitutions of the WTO, 17 Eur. J. INT'L L. 623 (2006).

22 Cho, Global Constitutional Process, supra note 3, at 621.

23 Report of the WTO panel, Mexico - Measures Affecting Telecommunications Services, WT/DS204/R (Apr. 2, 2004).

24 See Theodore Kill, The Evidence for Constitutionalization of the WTO, 20 Minn. J. INT'L L. 65, 122 (2011). 
constitutional handle gives the WTO the platform to connect to non-trade issues as well as it helps identify free market and consumer preference as some kind of a fundamental right. ${ }^{25}$

With the regular assault on multilateralism ${ }^{26}$ and the stalled Doha process, only a constitutional hermeneutics can possibly keep the WTO in business. But one has to note that the precedents for such constitutional visions have washed up the shores of the WTO from the EU experience. It is because of this that America sees constitutionalism as a distinctly European norm and thus not acceptable. Posner clearly admits this when he sarcastically remarks: "The American perspective on international law is wrong because it is not the European perspective, which has become law and is therefore right." ${ }^{27}$ But how do we know, Posner asks, "the Europeans got it right?" 28 Similarly, how does a third-worlder know if both the Europeans and Americans got it right?

\section{THE KADI EFFECT ON INTERNATIONAL LAW}

\section{A. Kadi: A Reminder}

The Kadi case arose from the EU regulation transposing the UN Security Council resolution's guidelines. ${ }^{29} \mathrm{Mr}$. Kadi, a British national of Saudi Arabian origin, challenged the EC's implementation of this resolution. It had identified him as being involved with terrorism and mandated that his assets be frozen. ${ }^{30}$ The ECJ delivered a judgment "annulling the relevant implementing measures and declaring that they violated fundamental rights protected by the EC legal order." 31 Here, the ECJ found, "and con-

25 Joost Pauwelyn, The Transformation of World Trade, 104 Mich. L. Rev. 1-65 (2005).

26 See generally, Jagdish Bhagwati, Termites in the Trading System: How Preferential Agreements Undermine Free Trade (2008).

27 See Eric A. Posner, A Response to Robert Ahdieh, OpInIo JURIs, available at http:// opiniojuris.org/2011/02/11/hilj_posner-responds-to-ahdieh/.

$28 I d$.

29 Kadi \& Al Barakaat Int'l Found. v. Council and Comm'n, Joined Cases C-402/05 $\mathrm{P}$ and C-415/05 P. Also, de Búrca, infra note 102, at 1.

30 Id.

31 Id. 
demned on EC law grounds, that the EC legislature had implemented a U.N. Security Council resolution providing for antiterrorist measures in such a way as to violate Mr Kadi's rights of defense." ${ }^{32}$ According to Búrca, the Kadi judgment spawns a "significant departure from the conventional presentation and widespread understanding of the EU as an actor maintaining a distinctive commitment to international law and institutions." 33

Notably, it also marks a complete swap in Europe's traditional position on international law. By analogy, in Kadi, the ECJ established the primacy of European constitutional concerns over international law. ${ }^{34}$ But the decision has also highlighted that the European review of lawfulness applies only to EC acts and never to acts of the Security Council under Chapter VII of the UN Charter. This is true even if such a review were to be limited to examination of the compatibility of that resolution with jus cogens. ${ }^{35}$

In the beginning, the ECJ did not challenge the existing hierarchy of norms within the international legal order. A question, however, must be asked: whether the primacy of UN Charter obligations is jeopardised due to Kadi? ${ }^{36}$ Advocate General Maduro advised the EC courts to determine the effect of international obligations within the EC legal order by reference to the conditions set by EC laws. ${ }^{37}$ Thus the ECJ, based clearly on the opinion of Maduro, ruled that the UN sanction led to the subversion of EU law and EU constitutionalism. ${ }^{38}$

\section{B. When Koskenniemi Locks Horn with Maduro?}

A power-based explanation of the Kadi judgment exposes the EU's increasing refusal to play second fiddle to the U.S. If the Security Council has been a puppet of the U.S., if seen from a Third World perspective, the

\footnotetext{
32 Bronckers, infra note 41, at 13.

33 de Búrca, infra note 102, at 2.

34 Albert Posch, The Kadi Case: Rethinking The Relationship Between EU Law and International Law? 15 Colum. J. Eur. L. OnLINe at 1 (2009).

$35 \quad I d$.

$36 \quad I d$.

37 Maduro, infra note 43, § III, g 23.

38 Nikolaos Lavranos, Judicial Review of UN Sanctions by the ECJ, 78 NORDIC J. INT'L L. 343-359 (2009).
} 
EU is now shifting the headquarters of international law to the ECJ. By spawning centrifugal constitutionalism, the ECJ is also pushing the ICJ into oblivion "due in large part to the failure of the Security Council to provide satisfactory due process protections." ${ }^{39}$ In fact, there is an apprehension that if the WTO has taken the economic aspect away and the ECJ has increasingly begun to "exercise its functions within the framework of customary international law," what is there for the ICJ to do? ${ }^{40}$

The ECJ is now the new centre of international law formation; it interacts with the International Tribunal for the Law of the Sea (ITLOS), the WTO and the ICJ - as Marco Bronckers puts it — with a "muted dialogue" as against the direct effect, as evidenced from its recent judgments. ${ }^{41}$ However, European lawyers have exhibited reluctance in accepting the ECJ's dualism. Therefore, constitutional lawyers have been seen using terms like "pluralist," "comprehensive pluralist," and "muted dialogue methodology" for the ECJ's new approach. ${ }^{42}$

In his analysis of the MOX Plant case, Koskenniemi criticised the ECJ for its dualism and disrespect for international law. He finds this disturbing. ${ }^{43}$ The Third World has to examine whether pluralism or constitutionalism within international law is yet another academic trope or a serious appreciation of global diversity. If it is the latter, are there opportunities, scope, and support for its normative translations for those who have watched international law's overtures from the periphery?

39 Devika Hovell, A House of Kadis? Recent Challenges to the UN Sanctions Regime and the Continuing Response to the ECJ Decision in Kadi, EJIL TALK! (July 7, 2009).

40 See Rosalyn Higgins, The ICJ, the ECJ, and the Integrity of International Law, 52 INT'L \& Comp. L. Q. 1, 17 (2003).

41 See, e,g., Marco Bronckers, From 'Direct effect' to 'Muted dialogue': Recent Developments in the European courts' case Law on the WTO and Beyond, J. INT'L ECON. L. 1-14 (2008).

42 Kirsch uses "pluralism," Rosenfeld uses "comprehensive pluralism," Přibáň says "Multiple Sovereignty" and Bronckers uses "Muted Dialogue" as against the express use of "Dualism." See Přibáň, Multiple Sovereignty: on Europes’s SelfConstitutionalization and Legal Self-Reference, 23 RATIO JuRIS 41 (2010).

43 See Martti Koskenniemi, International Law: Constitutionalism, Managerialism and Ethos of Legal Education, 1 EUR. J. LEGAL STUD. (2007). 


\section{Opposite Constitutional Narratives}

In the Kadi case, Maduro gave a powerful advisory opinion asserting EU constitutionalism. Maduro was very conclusive in his opinion. ${ }^{44}$ The ECJ in this case stood for the fundamental rights of its citizen. Kadi gave the ECJ an opportunity to deliberate on the relationship between the UN and EU in strictly legal terms. In Maduro's opinion, "the Community Courts have jurisdiction to review measures enacted by the Community in order to implement U.N. Security Council Resolutions. ${ }^{{ }^{455}} \mathrm{He}$ further opined that:

It would be wrong to conclude that, once the [European] Community is bound by a rule of international law, the EC Courts must bow to that rule with complete acquiescence and apply it unconditionally in the EC legal order. The relationship between international law and the EC legal order is governed by the EC legal order itself, and international law can permeate that legal order only under the conditions set by the constitutional principles of the EC. ${ }^{46}$ Essentially they [Council of EU \& Commission of the EC] argue that, when the Security Council has spoken, the Court [ECJ] must remain silent. ${ }^{47}$

He also referred to a US domestic decision - Justice Murphy's dissenting opinion of Korematsu v. United States. ${ }^{48}$ The assumption goes that one must respond and refer to domestic decisions of the U.S. Why? Perhaps, the U.S.'s domestic norms, unlike Third World states' norms, directly challenge international law. The U.S.'s supreme military power ensures that its norms do not go unnoticed. Never has a European or American court looked beyond Latin maxims to discover alternative rules of interpretations. The much vaunted globalization of legal knowledge, it seems, only means a further export of Euro-American rules to the Third World. The traffic of knowledge is decidedly one-way.

Koskenniemi's reactions to MOX Plant and Maduro's opinion in Kadi puts them in opposite camps. Both Maduro and Koskenniemi, among

44 See Maduro, infra note $43, \S \mathrm{v}$.

45 See Kadi, Maduro's Opinion, at 16, \$ iii, 19, 26, 27, 28 29, § iv, available at http://curia.europa.eu/jurisp/cgi-bin/form.pl?lang=EN\&Submit=rechercher\&nu maff $=\mathrm{C}-402 / 05$.

46 Id. 24 (emphasis added).

47 Id. 1. (emphasis added).

48323 U.S. 214, 233234 (1944). 
other significant European scholars, have sketched international constitutionalism's possible algorithm. Their approach, nonetheless, is completely divorced. Maduro advises for a dualist approach as discerned from his opinion in Kadi. MOX Plant that began at ITLOS is another possible site for a Maduro-Koskenniemi face-off. ${ }^{49}$ Citing MOX Plant - decided later by the ECJ - Koskenniemi says:

The MOX Plant case is stunning because it falls squarely on the oldest and most conservative trajectory of European thinking about the role of international law and its relations with national law. It shows the ECJ imagining the European Union as a sovereign whose laws override any other legal structure..$^{50}$

Maduro opined in MOX Plant as well: "Ireland has failed to fulfil its obligation under Article 292 EC and 193 EA." ${ }^{51}$ Though essentially a European debate, constitutionalism connects with the Third World due to its seductive potential. Baxi steps in at this point to declare that constitutionalism is "an unfamiliar guest to postcolonial discourse about the Third World." 52 Constitutionalism, he says, provides narratives of both rule and resistance. ${ }^{53}$

Post-Kadi, a proposed regulation by the EC provides for "a listing procedure ensuring that the fundamental rights of defence and in particular the right to be heard are respected." ${ }^{4}$ According to some, this measure threatens "to take decision-making about sanctions out of the hands of the Security Council and into the hands of a regional

49 MOX Plant Case (Ireland v. United Kingdom) ITLOS (provisional measures order, 3 December 2001) 126 ILR 334.

50 Koskenniemi, EJLS, supra note 43. Also See Nikolaos Lavranos, The MOX Plant And Ijzeren Rijn Disputes: Which Court Is The Supreme Arbiter? 19 LeIDEN J. INT'L L. 223 (2006).

51 Opinion, Miguel Maduro, Case C-459/03, Comm'n ECv. Ireland (Delivered on 18 January 2006), § I, 96.

52 Baxi, infra note 165 , at 540.

$53 \quad$ Id. at 548.

54 See Comm'n of the EC, 2009/0055 (CNS), Proposal for a council regulation amending regulation (EC) no 881/2002 imposing certain specific restrictive measures directed against certain persons and entities associated with Osama bin Laden, the Al-Qaida network and the Taliban, 5 (June, 28, 2010). 
body." ${ }^{55}$ It is only predictable given the EU's rise as our world's biggest normative laboratory.

\section{THE STATE OF INTERNATIONAL LAW IN THREE CONSTITUENCIES}

\section{A. United States of America: The Courts and Scholars}

Dennis Jacobs, an American judge thinks: "International law is not all about human rights, conflict, and the overlaying of international consensus on domestic law." ${ }^{56}$ International law, for the American judge, "is composed for the most part of well-developed, highly ramified systems of authority and order that facilitate life among nations." ${ }^{57}$ Despite recent polemics, according to some American scholars, "the use of international law in constitutional interpretation, as one factor among others, is highly traditional and eminently proper." ${ }^{58}$ Waldron asks of the value of customary international law, or of the enforceability of international law in American courts. ${ }^{59}$ Such sentiments about international law vis-à-vis American constitutional law, however, constitute a small percentage of constitutional lawyers.

A set of nationalist American lawyers interprets the Presidential war powers as arresting international law unconditionally. ${ }^{60}$ Jeremy Rabkin says that American “Self-Defense Shouldn't Be Too Distracted By Interna-

55 Hovell, supra note 39.

56 Dennis Jacobs, What Is An International Rule of Law? 30 HARv. J. L. \& Pub. Pol'y 3 (2006).

$57 \quad I d$. at 3.

58 Gerald L. Neuman, International Law As A Resource In Constitutional Interpretation, 30 Harv. J. L. \& PuB. Pol'y 177 (2006). (Some international law is too important to the place of the United States in the world for our constitutional jurisprudence to ignore; some international law provides useful functional or normative insights on which constitutional adjudication can draw). William H. Pryor Jr., Foreign And International Law Sources In Domestic Constitutional Interpretation, 30 Harv. J. L. \& PUb. Pol'y 173 (2006).

59 Jeremy Waldron, The Rule of International Law, 30 Harv. J. L. \& Pub. Pol'y 15 (2006).

60 Michael S. Paulsen, The Constitutional Power to Interpret International Law, 118 Yale L.J. 1762 (2009); Curtis A. Bradley, The Bush Administration and 
tional Law." ${ }^{11}$ Notably, American constitutional scholarship has recently been wielding its pen to arrest international law. The U.S. "Supreme Court has made it clear that both the President and Congress can break free of customary international law by simple decree." ${ }^{2}$ Rabkin challenges the critics' underlying premise that "international law has the same sort of claim on [U.S.] government as domestic law and that war measures abroad can accordingly be judged in the same terms as police abuses at home." ${ }^{63} \mathrm{~A}$ series of U.S. Supreme Court cases has also supported this position, more so during the war on terror. ${ }^{64}$ U.S. presidents have stretched or violated international law at significant moments in American history and international law has served as a political rallying point against the anti-terrorism policies of the Bush administration regarding the use of force, detention, interrogation, and military trial..$^{65}$ And,

Because "international law" has the same verbal form as "contract law" or "patent law," it is easy to fall into the trap of assuming that it has the same clarity or reliability as other kinds of law. If one looks at actual treatises on international law in the nineteenth century and down to quite recent times, one almost always finds an initial discussion of an apologetic nature, trying to address doubts about whether international law should truly be considered real law. Yet critics who protest that the Bush administration has "defied international law" in its war policies

International Law: Too Much Lawyering and Too Little Diplomacy, 4 Duke J. Const. L. \& Pub. Pol’y 57 (2009).

61 Jeremy Rabkin, American Self-Defense Shouldn't Be Too Distracted By International Law, Harv. J. L. \& Pub. Pol’y 31 (2006).

62 Saikrishna Prakash, The Constitutional Status Of Customary International Law, 30 Harv. J. L. \& Pub. Pol'y 65, 66 (2006); Michael D. Ramsey, The Textual Basis Of The President's Foreign Affairs Power, 30 Harv. J. L. \& Pub. Pol'y 141 (2006).

63 Rabkin, supra note 61, at 31.

64 United States v. Al Bahlul, 820 F.Supp.2d 1141 (C.M.C.R. 2011) (The U.S. Ct. of Military Comm'n Review held that the commission properly exercised jurisdiction over defendant); see John Kimpflen, War, 78 Am. Jur. 2d War $\$ 32$.

65 Robert J. Delahunty \& John Yoo, Executive Power V. International Law, 30 HaRv. J. L. Public Policy 73 (2006). 
speak as though international law has now achieved a degree of clarity, precision, and reliability that it never used to have. How could that be so?66

The American courts have also moved from their position in 1980 expressed in Fernandez v. Wilkinson that "even though the indeterminate detention of an excluded alien cannot be said to violate the United States Constitution or our statutory laws, it is judicially remedial as a violation of international law." ${ }^{\text {"77 }}$ Perhaps the most anti-international law judgment from a U.S. court came in Citizens Living in Nicaragua case where, inter alia, the Court said judgments of the ICJ "do not fall within the definition of jus cogens or peremptory norms of international law."68

The spate of cases after the 9/11 incidents, such as Khalid v. Bush, led the Court to hold that the U.S. "President's authority was not confined to capture and detention of persons on or near battlefields of Afghanistan."69 Invoking the separation of powers doctrine, the Court said that "it [is] impermissible to inquire into conditions of detention under international norms given President's authorization from Congress to detain combatants." 70 The U.S. Constitution was read as ossifying any cognizable constitutional rights of "non-resident aliens captured and detained outside" the U.S. in the war on terror. ${ }^{71}$

66 Rabkin, supra note 61, at 34.

67 Rodriguez Fernandez v. Wilkinson, 505 F. Supp. 787 (D.C. Kan. 1980).

68 Committee of U.S. Citizens Living in Nicaragua v. Reagan, 859 F.2d 929 (D.C. Cir. 1988). The Court also held that "despite claim that the Contras had begun targeting Americans living in Nicaragua, the funding of the Contras did not constitute a due process violation;" a statute inconsistent with customary international law modifies or supersedes that law to the extent of inconsistency; article of the UN Charter as to respecting judgments of the International Court of Justice does not confer rights on private individuals.

69 Khalid v. Bush, 355 F. Supp. 2d 311 (D.D.C. 2005).

$70 \quad I d$.

71 Id. U.S. v. Hamdan, 801 F. Supp. 2d 1247 USCMCR, (2011) held that the military commission, U.S. Naval Station at Guantanamo Bay, Cuba, had subject matter jurisdiction. See also Al-Bihani v. Obama, 619 F. 3d 1 (C.A.D.C. 2010). 
As the idea of transporting constitutional law to an international platform "tends to menace their ontological premise, i.e., state-centeredness," 72 American constitutional scholars offer a very minimum importance to this idea before international relations theory. Michel Paulsen and Curtis Bradley, standing on the extreme right, represent this brand of American view. They subordinate international law to the American constitution and the Presidential war powers. ${ }^{73}$ "To the extent that the regime of international law," Paulsen says, "yields determinate commands in conflict with the Constitution's commands or assignments of power, international law is, precisely to that extent, unconstitutional." ${ }^{74}$ No doubt, such attempts reminisces early twentieth century statist writings.

Posner and Goldsmith, extending this view further, distinguish between American and European international law; America sees itself as an exceptional nation, not bound by the rules that bind others. "The enormously successful, decades-long process of treaty-based European integration has," according to Posner and Goldsmith "led Europeans to identify peace and prosperity with a commitment to international law;"75 often what is overlooked is that the treaties that established the EU "created institutions that jealously guard the interests of Europeans when these interests conflict with an international law that reflects global aspirations." ${ }^{\prime 7}$

Accordingly, Paulsen thinks in general the charge that the U.S. has, in some respect or another, "violated international law" should have far "less rhetorical and political salience than it has had in public discourse." International law is not, in the main, law for the United States. ${ }^{78}$ This per-

72 Cho, Global Constitutional Process, supra note 3, at 622.

73 Paulsen, supra note 60, at 1762; Curtis A. Bradley, The Bush Administration And International Law: Too Much Lawyering And Too Little Diplomacy, 4 Duke J. Const. L. \& Pub. Pol’y 57 (2009).

74 Paulsen, supra note 60, at 1762. Bradley, ibid, at 57.

75 Jack Goldsmith \& Eric Posner, Does Europe Believe in International Law?, Wall St. J., November 25, 2008, available at http://online.wsj.com/article/ SB122757164701554711.html.

$76 \quad I d$.

77 Paulsen, supra note 60, at 1822.

78 Id. ("Where there exists a conflict between the U.S. Constitution's assignments of rights, powers, and duties, and the obligations of international law, U.S. 
haps "impolitic proposition is one that nevertheless needs to be confronted and embraced." 79 Now that Osama bin Laden is dead, finally, ${ }^{80}$ the "war on terror," of which Osama's death is an integral part, exposes American exceptionalism's disrespect for the international rule of law. Paulsen says: “Thus, whether Congress's justification for the authorizations of war in the September 18, 2001," and that vis-à-vis "the Iraq War satisfied international law requirements is of no consequence as a matter of U.S. law." ${ }^{11}$ Constitutionally, "these wars were legal, beyond question." 82 The question of international law compliance "is one of international politics and international relations, not one of binding U.S. law." ${ }^{33}$ After all, "a treaty may not foreclose Congress's constitutional power to declare war or the President's executive power with respect to war." 84

The force of international law, as a body of law, upon the United States is thus largely an illusion. On matters of war, peace, human rights, and torture - some of the most valued matters on which international law speaks - its voice may be silenced by contrary U.S. law or shouted down by the exercise of U.S. constitutional powers that international law has no binding domestic-law power to constrain. International law, for the United States, is international policy and politics. ${ }^{85}$

Perhaps this is what Eric Posner reinforces, yet again, in his co-authored idea of universal exceptionalism. ${ }^{86}$ America's "refusal to go along with other democratic states can be seen as another manifestation of Ameri-

government officials must, as a matter of legal obligation, side with the Constitution and against international law"). Id. at 1762.

79 Id.

80 Osama bin Laden is dead, Obama announces, The Guardian, 2 May 2011.

81 Paulsen, supra note 60, at 1823.

82 Id.

83 Id.

84 Id.

85 Id., at 1844.

86 Eric Posner \& Anu Bradford, Universal Exceptionalism in International Law, 52 Harv. Int'L L. J. 1 (2011). This position has been contested by Robert Ahdieh. See Robert Ahdieh, A Response to Anu Bradford and Eric A. Posner, OpInio Juris, available at http://opiniojuris.org/2011/02/11/hilj_ahdieh-response-to-bradfordposner/. 
can exceptionalism - here, "within the realm of judicial behavior and constitutionalism." ${ }^{87}$ In Osama's killing, clearly there was a violation of international humanitarian law on display and the U.S. President, who ironically holds the Nobel Peace Prize, exalted in these violations. The U.S. Constitution, according to Paulsen, empowers its President and the army to violate international law as and when needed..$^{88}$ Fortunately, there are many scholars who think Paulsen is not correct. ${ }^{89}$ However reckoning from the cases cited by scholars who favour the President and the Congress' ultimate power in trumping international law, and the scholars cited in the judgements of the U.S. courts, there is a strong symbiotic cross feeding to sustain each other. ${ }^{90}$

Id. at 11,91 .

88 Bradley guessed it right that "those who are assuming that President Obama will have radically different substantive positions on foreign policy than Bush may be disappointed." Bradley, supra note 60, at 78.

89 Neither the writings of anti-internationalist scholars nor the parchment of the Constitution itself will suffice to sustain America's (formerly) splendid constitutional isolation. This is the downside of formalism and the old constitutional law scholarship, which takes no account of learning from other disciplines or of empirical evidence. Developments on the ground are crucial to understanding the hydraulics by which international law will be imposed on the United States, constitutionally willing or not. Paulsen's analysis suffers from an ivory-tower blindness; it is compelling in an antiquarian, parlor-game sort of way. Peter J. Spiro, Wishing International Law Away, 119 YALE L.J. OnLIne 23 (2009), available at http://yalelawjournal.org/2009/09/29/spiro.html. Pointing to lacunas in Paulsen's advocacy, Ku says, "Yet obeisance to the Constitution does not render international law a meaningless illusion." In fact, "the Constitution allocates to Congress and the President the power to transform international law into binding domestic law that is as binding as any other kind of U.S. law. For better and for worse, then, international law will continue its co-existence with constitutional law as an important form of law for the United States." Julian Ku, The Prospects for the Peaceful Co-Existence of Constitutional and International Law, 119 YALE L.J. OnLine 15 (2009), http://yalelawjournal.org/2009/09/29/ku.html. (emphasis in original).

90 For example, most of the cases that deal with war on terror detainees have cited Bradley, Goldsmith, Posner, and the like. See Al-Bihani v. Obama, 619 F. 3d 1 (C.A.D.C. 2010); al-Marri v. Pucciarelli, 534 F.3d 213, C.A.4 (S.C.), July 15, 2008 
Quite remarkably, Karl Popper's attack on Hegel's constitutionalism becomes important here. ${ }^{91}$ Popper explains that Hegel's support for equality and liberty came from his allegiance to Prussian absolutism of the totalitarian Frederick William III. ${ }^{92}$ Just as Hegelian équilibre came from totalitarianism, American scholars' isolationism comes from well-known American exceptionalism.

\section{B. The European Union}

In NS v. Secretary of State for the Home Department, ${ }^{93}$ the ECJ in relation to the removal of an asylum seeker to Greece, held there was a strong but rebuttable presumption that a Member State would abide by the European Convention of Human Rights, as the common European asylum system was based on the assumption that states would abide by this Convention.

At issue here is the raison d'être of the European Union and the creation of an area of freedom, security and justice and, in particular, the Common European Asylum System, based on mutual confidence and a presumption of compliance, by other Member States, with European Union law and, in particular, fundamental rights. ${ }^{94}$

Most recently in Pye Phyo Tay Za v. Council of the EU, ${ }^{95}$ the ECJ gave a judgment that in both procedure and substance is parallel to Kadi. ${ }^{96}$ Typi-

(NO. 06-7427). See Curtis A. Bradley, Enforcing The Avena Decision In U.S. Courts, 30 Harv. J. Law \& Public Policy 119 (2006).

91 II Karl Popper, The Open Society and Its Enemies: Hegel and Marx, 47-48 (2010).

92 Paulsen, supra note 60, at 28.

93 N.S. $v$ Sec'y of State for the Home Dep't. (C-411/10 and 493/10, 21 December 2011).

94 Id. at 83, quoted in Krolik v Poland, 2012 WL 3491932, [2012] EWHC 2357 (Admin) at 5 .

95 Tay Za v. Council of the EU (C-376/10 P), the ECJ, (Grand Chamber) (Mar. 13, 2012).

96 In Pye Phyo Tay Za, the ECJ gave a judgment that in both procedure and substance is parallel to the Kadi and Al Barakaat International Foundation v. Council and Commission, Joined Cases C-402/05 P and C-415/05 P. The ECJ ruled that a measure to freeze funds and economic resources belonging to appellant Pye Phyo Tay $\mathrm{Za}$ "could have been adopted within the framework of a regulation intended 
to impose sanctions on a third country on the basis of Articles 60 EC and 301 EC only in reliance upon precise, concrete evidence which would have enabled it to be established that the appellant benefits from the economic policies of the leaders of the Republic of the Union of Myanmar." Id. 70. (emphasis added). The General Court [earlier the Court of First Instance] erred in law in "presume[ing] that the family members of leading business figures benefit from the functions exercised by those businessmen, so that such family members also benefit from the economic policies of the government, and that there is therefore a sufficient link, for the purposes of Articles $60 \mathrm{EC}$ and $301 \mathrm{EC}$, between the appellant and the military regime of Myanmar." Id. 71 . The General Court examined whether there was a sufficient link between the appellant and the leaders of Myanmar capable of justifying the adoption of restrictive measures in respect of the appellant on the basis of Articles 60 EC and 301 EC." Id. 44. This was done in the light of Kadi. The issue for the ECJ in the Tay Za case was to determine whether "there is a presumption that the family members of those in charge of major businesses under the military regime in Myanmar benefit from the function performed by those persons, so that it is permissible to conclude that those family members also benefit from the economic policies of the government of that country." Id. 45. The lower court, in the ECJ's view "correctly applied the Court's case law on the scope of Articles 60 EC and 301 EC, as established, in particular, by Kadi." Id. In accordance with the Treaty on European Union, Article 301, relating to the common foreign and security policy, for an action by the Community to revise economic relations with third countries, the EC is to take the necessary urgent measures. Id. 48. For this however, it is necessary for this case, the ECJ ruled, "to ascertain whether, in reaching that conclusion, the General Court erred in law as regards the scope of Articles $60 \mathrm{EC}$ and $301 \mathrm{EC}$, as interpreted by the case-law of the Court of Justice (see, inter alia, Kadi)." Id. 59. When on the basis of Articles $60 \mathrm{EC}$ and $301 \mathrm{EC}$ a restrictive measure is imposed on third country or countries, "the measures in respect of natural persons must be directed only against the leaders of such countries and the persons associated with those leaders." Id. 63. Naturally according to the existing EU Treaty, that requirement mandates the tangible link between the persons concerned and the third country targeted by the restrictive measures adopted by the EU, "precluding too broad an interpretation of Articles $60 \mathrm{EC}$ and $301 \mathrm{EC}$ which would therefore be contrary to the Court's case-law." Id. 64. Thus by "presum[ing] that the family members of leading business figures also benefit from the economic policies of the government, the General Court extended the category of natural persons who may be subject to targeted restrictive measures." Id. 65 . The application of such measures to natural persons the ECJ ruled, "on the sole ground of their family connection with persons 
cally, western "constitutionalism views a constitution as the guardian of fundamental rights through constraining government power, including limited government, separation of powers, checks and balances, and judicial review. ${ }^{97}$ "With the formation of the EU, naturally, an idea of a Europewide constitutional protection of fundamental rights is further reinforced. For instance, in 2012 the ECJ in Germany v. B, held because a person had been a member of an organisation which, by virtue of its involvement in terrorist acts, was on the European Commission's (EC) particular list and that that person had actively supported the armed struggle waged by that organisation did not automatically constitute a serious reason for considering that that person had committed, inter alia, "acts contrary to the purposes and principles of the UN." ${ }^{98}$ Germany v. B is a logical continuation of the ECJ's Kadi judgment. ${ }^{99}$ Likewise in Secretary of State for the Home Department, ${ }^{100}$ the UK High Court of Justice stopped short of recognizing a right to Internet access on a monitored computer to a British national of Iranian origin.

Thus the position of the ECJ is much more pro-human rights than the general position of the U.S. courts even in the wake of the ongoing war on terror. ${ }^{101}$ Much of the American disrespect for international law, as seen in the interpretation of its constitution, comes from Europe's normative

associated with the leaders of the third country concerned, irrespective of the personal conduct of such natural persons, is at variance with the Court's case-law on Articles 60 EC and 301 EC." Id. 66. Moreover, the ECJ observed, "the criterion used by the General Court in order to include the family members of those in charge of businesses is based on a presumption for which no provision was made in the contested regulation or in Common Positions 2006/318 and 2007/750, to which that regulation refers, and which is inconsistent with the objective of the regulation." Id. 69. (emphasis added).

97 Yeh \& Chang, supra note 10, at 834.

98 This consideration was to be done within the meaning of article 12(2)(b)(c) of Council Directive 2004/83/EC and the list forming the Annex to Common Position 2001/931/CFSP. Germany v. B (C-57/09), [2012] 1 W.L.R. 1076.

99 Kadi, supra note 29.

100 Sec'y of State for the Home Dep't v. CE (Iran), 2011 WL 6329010, Queen's Bench Division (Administrative Court).

101 See Kim Lane Scheppele, Global Security and the Challenge to Constitutionalism after 9/11, Puв. L. 353 (2011). 
dominance of international law. Since the UN system is often seen as the puppet of the U.S., there are some obvious signs of anti-UN version of international law that the Kadi decision of the ECJ reflects. ${ }^{102}$ Kadi stands to question Article 103 of the UN Charter that puts UN law above any other law, even EU constitutional priorities. From the point of view of individual human rights, given the UN terrorism committee's arbitrariness in listing terrorists for the freezing of funds, Kadi is certainly welcome. Kadi represents Europe's attitudes toward the international "rule of law."103 The ECJ held that Kadi had the right to be heard and a listing of his name as a suspect terrorist was done arbitrarily, violating his fundamental rights enshrined in the EU constitutional process. Even for the EU, its constitutional law mandates the trumping of international law, although it seeks to safeguard individual human rights at the same time. Understandably, on the issue of Kadi the Americans and the Europeans stand on opposite sides of the battleground. ${ }^{104}$

102 From a third world viewpoint, current literature on "pluralism" after Kadi simply recasts dualism. For centuries monism - employed by First World countries - has been identified with respect for international law. Dualism, in opposition to respect, reflects the Third World's scepticism about international law. New scholarship from the First World, therefore, does not want to accept its new dualism. According to Búrca, pluralist approaches to the international legal order "claim to preserve space for contestation, resistance and innovation and to encourage tolerance and mutual accommodation." Gráinne de Búrca, The ECJ and the International Legal Order after Kadi, 51 HARv. INT'L L. J. 1, 2 (2010). Discouraged by the impossibility of any viable global federal structure, Rosenfeld, a pluralist, advocates an ideological alternative to accommodate the plurality of legal regimes. One of the most "vexing problems facing the post-Westphalian legal order is the apparent demise of the Kelsenian model based on hierarchy, unity, and consistency." If unity could be replaced by plurality and consistency by comprehensive pluralism's standard of compatibility, Rosenfeld feels we can find an answer to the layered and segmented development of the evolving legal universe. Pluralism applauds diversity, competition, and lack of coordination in the global sphere. The chances, therefore, of a healthy degree of global accountability are higher in a pluralist reading of international law. Michel Rosenfeld, Rethinking constitutional ordering in an era of legal and ideological pluralism, 6 INT'L J. CONST. L. 415 (2008).

103 Kadi, supra note 29.

104 See generally, Goldsmith \& Posner, supra note 75. 
According to Posner and Goldsmith, based on the record, Europe "has no grounds to criticize the U.S." 105 In other words, "European countries must disregard the UN Charter - the most fundamental treaty in our modern international legal system - when it conflicts with European constitutional order. ${ }^{106 "}$

This is the third time in a decade that Europe has defied the U.N. Charter. In 1999, for example, European nations participated in NATO's bombing of Kosovo without Security Council authorization. There was much hand-wringing in Europe at the time, but in the end other concerns trumped legal niceties. Similarly, when nations led by Europe created the International Criminal Court, they purported to limit the Security Council's power to delay or halt ICC trials, also in disregard of the U.N. Charter, which states that Charter obligations trump the requirements of any other treaty. ${ }^{107}$

More particularly, the American dislike for a constitutional interpretation of WTO law and related agreements comes from its losses in several anti-dumping cases. ${ }^{108}$ Little surprise then that after "losing a series of zeroing cases under the WTO dispute settlement mechanism, the United States proposed that zeroing be ultimately resolved through negotiations, instead of being left to adjudication." 109

What is nonetheless remarkable here is that European commentators do not see this as ECJ's dualism. The ECJ, we are said, has been taking a pluralist approach. In the vocabulary of European lawyers, in Kadi the ECJ, "following the opinion of AG Maduro, adopted a robustly pluralist approach to the relationship between the EU and the international order." 110 Pluralist approaches share with dualism the emphasis on separate and distinct legal orders. ${ }^{111}$ Pluralism, however, "emphasizes the plurality of

\footnotetext{
105 Id.

106 Id.

107 Id. 97.

108 Mark Wu, Antidumping in Asia's Emerging Giants, 53 Harv. Int'L L. J 1 (2012).

109 Cho, supra note 3, at 649.

110 de Búrca, supra note 102, at 31-32.

111 Id.
} 
diverse normative systems, while the traditional focus of dualism has been only on the relationship between national and international law." 112

Kettemann's defence of the European approach to international law is good enough to tell the Third World about the kind of game international law is. ${ }^{113}$ On the one hand, he refuses to accept Goldsmith and Posner's interpretation of the Kadi judgment that "[1]ike the Bush administration, Europeans obey international law when it advances their interests and discard it when it does not."114 On the other hand, he concedes "that Europe's approach to trade disputes in the framework of the WTO has not been exemplary." 115 Admittedly, Europe made errors but also corrected some of it later. ${ }^{116}$

\section{India}

As compared to the existing robust debate in Europe and America about their less-than-robust respect for international law, Indian views are hard to come by. The article will therefore construct this Indian view from court cases and writings of qualified publicist from India. ${ }^{117}$ One is then tempted to compare the American and European approach to how Indian police captured Kasab, the terrorist who conducted the infamous 26/11 attacks in Mumbai, and chose to try him before district trial court under Indian criminal law for "murder, conspiracy and of waging war against the nation." 118 India, unlike the EU, is clearly dualist and pluralism of legal order is part of its federal structure through the division of competencies in

$112 I d$.

113 Matthias Kettemann, International Law is like a Box of Chocolates, THe Records, Feb. 12, 2010, available at http://hlrecord.org/?p=9560.

114 Id.

115 Id.

116 Id.

117 V. G. Hegde, Indian Courts, and International Law, 23 Leiden J. INT'L L. 53-77 (2010).

118 NDTV, 26/11 Mumbai attack: Kasab’s trial (Monday May 3, 2010). The New York Times reported "Even by the standards of terrorism in India, which has suffered a rising number of attacks this year, the assaults were particularly brazen in scale and execution." See Somini Sengupta, At Least 100 Dead in India Terror Attacks, N. Y. Times, Nov. 27, 2008 at A1. 
three lists of its constitution. They are union, state province) and concurrent list. ${ }^{119}$ In article 51, the Indian constitution expects India's endeavour to:

(a) promote international peace and security;

(b) maintain just and honourable relations between nations;

(c) foster respect for international law and treaty obligations in the dealings of organized peoples with one another; and

(d) encourage settlement of international disputes by arbitration. ${ }^{120}$

Soon after Kasab's arrest, Indian lawyers noted, “certain basic procedural safeguards evolved by the Supreme Court have not been followed so far in the case of Kasab." ${ }^{121}$ Natural justice entails some legal aid to the party to render her defence meaningful. The Indian Supreme Court has developed ample jurisprudence on the subject. The Court, in the case of N Satpathy v. PL Dani, ${ }^{122}$ allowed legal representation during custodial inter rogations. In AK Roy v. Union of India, ${ }^{123}$ the Court held that even a détenu "who is statutorily denied legal representation is entitled to a common law right of representation through a friend. ${ }^{124 "}$

By including "the right to free legal aid" in Article 21 of the Constitution in the $\mathrm{MH}$ Hoskot case ${ }^{125}$ the Court gives it a constitutional status. No doubt, the initial threats and intimidation of Indian lawyers who wanted to defend Kasab did bring some disrepute to the Indian legal system. ${ }^{126} \mathrm{On}$

119 India Const., Seventh Schedule, available at http://lawmin.nic.in/coi/ coiason29july08.pdf, at pp. 316-29. The Union list has 97, state 66 and concurrent list has 47 items. When an issue is not part of the state or concurrent list, the Union of India automatically has the competence to legislate on this.

120 Id.

121 V. Venkatesan, Due Process: There is a strong case under the country's laws for Kasab's right to legal assistance, 26(2) FrontLine, Jan. 17-30, 2009, at 15 available at http://www.hindu.com/fline/fl2602/stories/20090130260203300.htm.

122 Nandini Satpathy v. PL Dani, (1978) 2 SCC 424 (India).

123 A.K. Roy v. Union of India 1982 AIR 710 (India).

124 Venkatesan, Due Process, supra note 121, at 15.

125 MH Hoskot v. State of Maharashtra, (1978) 3 SCC 544: AIR 1978 (India).

126 Venkatesan, Due Process, supra note 121, at 4. 
September 18, 2012 Kasab moved a mercy petition praying for clemency against the death sentence awarded to him by the trial court, affirmed by the Bombay High Court, and upheld by the Supreme Court. ${ }^{127}$

\section{i. The Kasab Case}

In November 2008, Mohammad Ajmal Amir Kasab, allegedly a Pakistani national, was the sole survivor among the 10 gunmen who killed more than 160 people in the Taj Hotel, a Jewish center, and a busy railroad station in Mumbai, India. Police sprang into action and captured Kasab.

He was not killed the American way and India seemed to take a more European approach of protecting the due process rights as argued in Kadi. India, perhaps has learned it lessons from the infamous Indian Emergency of 25 June 1975 enforced by Prime Minister Indira Gandhi; that period was to become, as many regrettably admit, the darkest years of the Indian judiciary. Harking back to the criticisms of the infamous A.D.M. Jabalpur case $^{128}$ delivered by the Supreme Court during the Emergency, Venkatesan says

... [it] is clear that rights can exist outside Constitutions and one should be wary of arguments that seek to take away such rights." ${ }^{129}$ In this case, the Indian Supreme Court held that "the legality of the order of detention issued during the Emergency could not be challenged in a court of law as the Presidential Order had suspended the right to move any court to enforce rights under Articles 14, 21 and 22 [of the Indian Constitution]. ${ }^{130}$

From the time of his capture, there was an irrefutable case under the Indian Constitution for Kasab's right to legal assistance and the Indian state's duty to provide it. However, as was expected, Subramanian Swamy, a former visiting faculty at Harvard University and a right wing leader, suggested that Kasab could be considered an enemy alien under Article 22(3)(a) and deprived of the right to legal assistance. However, using constitutional logic,

127 Mumbai Bureau, Kasab’s plea forwarded to President, The Hindu, Sept. 18, 2012, available at http://www.thehindu.com/news/national/article3910505.ece.

ADM Jabalpur v. Shiv Kant Shukla, 1976 SCC (2) 521 (India).

129 Venkatesan, supra note 121 , at 9.

$130 I d$. 
his political claim may be negated. ${ }^{131}$ The primary objection in treating Kasab as an enemy alien, Venkatesan opines, stems from Article 21 of the Indian constitution. ${ }^{132}$ In the Pratap Singh case, the Supreme Court said that the Legislature did not make law in disregard of the constitutional provisions or the international law as also in the context of Articles 20 and 21 of the Constitution of India. ${ }^{133}$ The law has to be understood, therefore, in accordance with international law. ${ }^{134}$ Article 21 guarantees the right to life or personal liberty to even non-citizens. ${ }^{135}$ Under this Article, no person shall be deprived of his life or personal liberty except according to procedure established by law. ${ }^{136}$ It is true that the conventional understanding of war has changed. In the Parliament attack case, ${ }^{137}$ the Supreme Court said that:

[for] invoking Section 121 of the Indian Penal Code (punishment for waging of war), a formal declaration of war was not required: a terrorist attack by militants from across the border, with their accomplices in India, on the symbols of state power was sufficient to infer that a war-like situation prevailed. ${ }^{138}$

Kasab and his accomplices could be said to have waged war with India for the purpose of their prosecution, "but they cannot be considered enemy aliens under international law and deprived of rights accorded to noncitizens under the Indian Constitution." ${ }^{139}$ Quite rightly, India did not even contemplate this option. The danger in treating Kasab as an enemy alien,

131 Article 22(1) of the Constitution provides that no person who is arrested shall be detained in custody without being informed, as soon as may be, of the grounds of such arrest, nor shall he be denied the right to consult, and to be defended by, a legal practitioner of his choice. $I d$.

132 Id.

133 Pratap Singh v. State of Jharkhand, (2005) 3 SCC 551 (India) at 63.

134 Id.

135 Id.

136 Id.

137 Through Writ Petition (Crl. No.106/2007) the accused Afzal Guru approached the Supreme Court. His counsel, Mr. Bhushan, relied on Shamnsaheb M. Multtani v. State of Karnataka, AIR 2001 SC 921 (India).

138 Venkatesan, supra note 121.

139 Id. 
Venkatesan thinks, would be that of setting an unhealthy precedent. ${ }^{140}$ Before the Indian Supreme Court, Ramchandran, lawyer for Kasab, "submitted that the Appellant did not get a fair trial and added that the denial of fair trial, for any reason, wittingly or unwittingly, would have the same result: it would render the trial a nullity and no conviction or sentence based on such a trial would be legal or enforceable." 141 He prefaced his submissions by gently reminding the Court that, "having taken the path of the rule of law, we must walk the full mile; we cannot stop halfway and fall short of the standards we have set for ourselves. ${ }^{142}$ "In paragraph 586, the Indian Supreme Court, however, affirmed the convictions and death sentence of the Kasab passed by the trial court and affirmed by the High Court.

\section{ii. India's Attempt at Protecting International Law}

The Kasab case is important to distinguish between the Indian state and the Indian judiciary. The Indian state (bureaucracy) is dualist. ${ }^{143}$ However, since the 1980s, the Indian judiciary, which has the power of judicial review, is gradually moving to monism as exhibited in over a dozen judgments. Overall, India is moving toward monism as far as terrorism and international human rights are concerned though much more remains to be done. Thus, between Osama, Kadi, and Kasab, the three jurisdictions' real respect for the rule of international law is exposed.

Larger questions emerge; who among the three respects the rule of law the most? Has not the Third World, India in particular, displayed a remarkable faith in the idea of law and justice through fair trial? Did not the EU violate international law in Kadi when it stood against its own constitutional priorities? Did not the American government violate international law in the killing of Osama?

140 "Article 22 is not the sole repository of the right to counsel, especially for Kasab, who is not an Indian national. So, that provision is not the sole determinator of his rights. And, it would be patently unfair to subject him to the demands of that provision alone." Id. $\mathbf{g} 17$.

141 Mohammed Ajmal Mohammad Amir Kasab @ Abu Mujahid v. State of Maharashtra, MANU/SC/0681/2012, (India) 408.

142 Id.

143 Jolly Jeorge v. Bank of Cochin, AIR 1980 SC 470 (India). 
The Kasab case has led to the development of a very healthy debate on human rights in India. However, on August 29, 2012 ,the Supreme Court finally upheld Kasab's death sentence. ${ }^{144}$ Kasab's case, Surendranath thinks, "is a significant setback for the move towards complete abolition of the death penalty in India." 145 As though it is an acknowledgment "that there will be moments in our life as a nation where we will need to satisfy our need for collective revenge." ${ }^{146}$ By comparing Kasab's case with Judge Yagnik's "invocation of human dignity while not awarding the death penalty in the Naroda-Patiya massacre case" India human rights lawyers talks about the "constitutional unviability of the death penalty in India. ${ }^{147}$ However, the President of India rejected Kasab's mercy petition on November 5, and subsequently he was hanged on November 21, 2012.

\section{DEVELOPING COUNTRIES AND CONSTITUTIONALISM}

\section{A. Monism, Dualism and Constitutionalism}

The ECJ is the epitome of the collective EU view; it has emerged as the chief protagonist of a pluralist view of the international legal order. Kadi and MOX Plant ${ }^{148}$ are two of the many such cases discussed later. These two cases also amplify the ECJ's increasing importance in international law's overhauling. As a result, the old monism-dualism prism to refract a country's adherence to international law is under fire today. Bogdandy, chief architect of this view, thinks, "as theories, monism and dualism are today unsatisfactory." 149

144 Mohammed Ajmal Mohammad Amir Kasab@Abu Mujahidv State of Maharashtra, MANU/SC/0681/2012.

145 Anup Surendranath, Death is Entirely Discriminatory, The Hindu, Sept. 17, 2012, at http://www.thehindu.com/opinion/lead/article3904606.ece.

146 Id.

147 Id.

148 Case C-459/03, Eur. Comm'n v Ireland, 30 May 2006.

149 Armin von Bogdandy, Pluralism, Direct Effect, and the Ultimate Say: On the relationship between International and Domestic Constitutional law, 6 INT'L J. Const. L. 397-413, 400 (2008). De Búrca and Gerstenberg have argued on similar lines. They think "international adjudication should be conceived of as having a 
Core assertions behind monism-dualism, he maintains, "are little developed and opposing views are simply dismissed as illogical, and they are not linked with the contemporary theoretical debates." 150 As a doctrine, monism-dualism is likewise unsatisfactory since it does not help in solving legal issues. ${ }^{151}$ Thus monism and dualism should cease to exist as doctrinal and theoretical notions for discussing the relationship between international and internal law. ${ }^{152}$ However, Somek questions Bogdandy's excessive liberty taken in replacing the monism-dualism prism by pluralism or cosmopolitanism. ${ }^{153}$

Nonetheless, this European shift from the monism-dualism doctrine seems suspect as, historically speaking, the developed world offered a monist and the non-developed a dualist treatment to international law. This is also the EU's centrifugal constitutionalism on display; a kind of constitutional advocacy where the European concerns colour the EU's international advocacy. The domestic norms of Europe govern its compatibility with international norms. Thus, the nations that historically offered a monist treatment to international law have moved to dualism. But instead of clearly admitting it, EU scholars claim to have moved to pluralism. Therefore, these developments need an evaluation from a Third World angle.

A constitution, as understood in national terms, is the best form of the legal tool that works discursively to limit the use of power in a democracy. Arguably, it is an effort to clothe global regulation by a network of legality. ${ }^{154}$ It is also an ideology or a juristic export of a constitutional vision to

persuasive function and not an overriding one. International and constitutional norms should be understood as contextually competing rule-of-law values rather than as conflicting legal sources vying against one another" in Gráinne de Búrca and Oliver Gerstenberg, The Denationalization of Constitutional Law, 47 HARv. INT'L L. J. 243-62 (2006).

150 See Bogdandy, ibid.

151 Id.

152 Id.

153 Alexander Somek, Monism: A Tale of the Undead, Univ. Iowa Legal Stud. Research Paper No. 10-22, available at http://papers.ssrn.com/sol3/papers.cfm?abstract_ id $=1606909$.

154 Philip Bobbitt, Terror and Consent 485 (2008). 
the international plane. But very often the interpretations of a constitution evidence an unabashed reflection of contemporaneous politics, rather than the pursuit of a legal doctrine.

The situation is no different at international fora - the Security Council, the WTO, and many other international bodies. Before the WTO Appellate Body (AB), in India-Quantitative Restrictions on Imports Of Agriculture, Textile and Industrial Products (India-QRs) ${ }^{155}$ India read the WTO treaty as a constitution and the AB as an international constitutional court. ${ }^{156}$ Indeed as Indian experience has shown, "under certain circumstances global organizations may self-generate constitutional norms in an effort to regulate states' behaviors that ambiguous treaty provisions may not fully capture." 157 This case is stunning given not many developing countries exhibit such a faith in international constitutional architecture. ${ }^{158}$ Cho further demonstrates "why, and how, the recent WTO zeroing jurisprudence can be appreciated as a form of constitutional adjudication." 159

\section{B. Constitutional Interpretations as a Value Question}

The Third World embraced constitutionalism throughout the 1960s and 1980s with much pain and political upheavals. These constitutional concepts and structures had actually migrated from the colonisers. Baxi has observed the transformations "which newly independent nations such as India have worked on supposedly universal standards of legal rights in writing and amending their national constitutions." ${ }^{160}$ However, as discussed

155 Report of the Appellate Body, India-Quantitative Restrictions on Imports Of Agriculture, Textile and Industrial Products WT/DS90/AB/R (23 Aug. 1999).

156 Dunoff, supra note 3, at 657-58.

157 Cho, supra note 3, at 622.

158 Colin Picker argues, "To the extent that international trade and development policy employs legal methods, institutions and participants, there is a need to take into account the role of legal culture." See Picker, International Trade and Development Law: A Legal Cultural Critique, 4 (2) L. Dev. Rev., Article 4 (2011), available at http://www.bepress.com/ldr/vol4/iss2/art4/.

159 Cho, supra note 3, at 676.

160 Baxi, infra note 165 , at 540. 
later, Third World constitutionalism still suffers from colonial marks and memories. In Premanand v. Mohan Koikal, ${ }^{161}$ Justice Katju reminded:

[t]he Constitution of India [does not say] that only Maxwell's Principles of Interpretation can be utilised. We can utilise any system of interpretation which can help to resolve a difficulty. Principles of interpretation are not principles of law but are only a methodology for explaining the meaning of words used in a text ... [in the current case] literal rule of interpretation will prevail over all other [Mīmānsā] principles, e.g., Linga, Vakya, Prakarana, Sthana, Samakhya.

Jaimini’s (ca. 3rd to 1st century BCE) Purva Mìmānsā Sutras is the primary text of the Mīmānsā School. Later in Kumārila Bhata and Prabhākara, this school reached its pinnacle (fl. ca. 700 CE). ${ }^{162}$ Actually in 1892 Sir John Edge, the then Chief Justice of Allahabad High Court, was the first and the last English judge to apply Mīmānsā rules of interpretation in Beni Prasad v. Hardai Bibi ${ }^{163}$ as the case involved a family issue needing reference to Hindu personal laws. Since then Mìmānsā has been seen not as a secular but a Hindu rule of interpretation. This position is contested, as Mìmānsā has been a tool of Indian linguistics and not religion.

However, one of the major problems with the use of Mimañnsā is that it is not a set of legal rules of interpretation; it is primarily is a tool to deconstruct Sanskrit sentences for further interpretation, social and philosophical. Apart from the nationalistic urge to go back to the golden times of ancient India, the judges of the Indian Supreme Court, especially Justice Katju, have not been able to justify its use over the regular methods and rules of interpretation. It is because of this that Mìmānsā has not been used even once in international courts for interpretation. Mìmānsā in that sense appears only a value based tool for interpretation.

Nonetheless, one may note that Article 31(3)(c) of the Vienna Convention on the Law of Treaties has been pulled out of oblivion only recently, and international institutions in the past have shown scanty respect for alternative methods, means, and interpretations. This is the only article that

\footnotetext{
161 MANU/SC/0249/2011 (India); g9 24, 25, 38.

162 See Vijay Narayan Thatte and Ors. v. State of Maharashtra and Ors., 9 SCC 92, 8 (2009) (India). 
could be used towards importing non-European perspectives, Mìmānsā for example, into the decision making of international bodies. ${ }^{164}$ Yet there remains a less than robust case for Mìmānsā replacing the regular rules of interpretation. It nonetheless is a promising research area for developing secular rules of legal interpretations. ${ }^{165}$

With the idea of constitutionalism now firmly rooted in the Third World, the Indian Supreme Court opined that regrettably, Indian lawyers mostly quote western authorities at the expense of Mìmānsāa, the Indian rules of interpretation. ${ }^{166} \mathrm{Katju}$, the more dominant supporter of these alternative Indian rules of interpretation, is not alone to have asserted a local approach to constitutionalism. ${ }^{167}$ Referring to the scepticism about the Caribbean Court of Justice being the final appellate court for the Caribbean countries, Justice Ivor Archie, remarked in a rather postcolonial mood: "If we have the moral and intellectual capacity to run our own

164 See Campbell McLachlan, The Principals of Systemic Integration and Art. 31.3.(C) of the Vienna Convention, 54 INT'L \& ComP. L. Q. 297 (2005).

165 Some of the basic books on interpretations were both translated and authored by Dr. Sir Ganganath Jha during 1900-25. Jha has discussed many interpretive methods of pre-British Vedic India where Mìmānsā was a method of interpretations. See Vepa Sarathi, Statuary Interpretations, $8-10$, ( $5^{\text {th }}$ ed., 2010). First, the Indian Supreme Court enunciated in the seventies an unusual province and function for judicial review by declaring that the power of Parliament to amend the Constitution was subject to judicial review: it may not extend to alteration of the essential features of the basic structure of the Constitution. What these "essential features" were, was left for the Justices to enunciate from time to time, but these included the "rule of law," "republican form of government," "federalism," "democracy," "socialism," "secularism," and above all the power of judicial review. The doctrine was not merely enunciated; it was also applied to invalidate several amendments ... And this form of adjudicatory activism has, in turn, traveled to Pakistan, Bangladesh, and Nepal. Upendra Baxi, Postcolonial Legality, in, A Companion to Postcolonial Studies, 548 (Henry Schwarz, Sangeeta Ray eds. 1999).

166 See Tannu Sharma, To settle case, SC turns to Mimamsa, The Indian Express, March 14, 2008.

167 M. Katju, Mìmānsā Rules of Interpretation (2008). 
countries in the region, why can we not judge ourselves?"168 "That somehow we will receive a superior kind of justice from London bespeaks of selfdoubt and an unwillingness to take responsibility for our jurisprudential self-determination." 169

\section{A THIRD WORLD APPROACH TO CONSTITUTIONALISM}

The existence of a constitution and the separation of powers - legislative, administrative, and judicial - have a strong bearing on India's advocacy in international courts, e.g., the WTO. The India-QR case, as discussed below, is a testimony to that. The constitutional addiction of the Third World is simply remarkable; a case of trope taken seriously by the Third World at a time when international law's makers are swapping its position on international law. As pointed out earlier, India's obsession with a constitutional imagery - this comes from India's remarkable experience with its judiciary - was rejected and discouraged by the WTO AB. Yet, as Cho thinks, "the AB's anti-zeroing position ... is tantamount to "constitutional lawmaking" in its determined endeavor to contain WTO members'

168 Ivor Archie, There Must Be A Change in Culture, The Guardian, Trinidad and Tobago, Sept. 17, 2010.

$169 I d$. Such experiences with constitutional grafting and jurisprudential selfdetermination, as judge Archie puts it — which may easily be generalised for the rest of the Third World with its regional flavours — prefaces Hirschl's remark about the rise of "Constitutional Theocracy." See Ran Hirschl, The Rise of Constitutional Theocracy, 49 HARv. Int'L L. J. OnLIne 72, 73 (2008). He observes the resurrection of theocratic forces within the democratic setup around the world. A closer look tells us that these states are mostly Third World states. The world has, Hirschl remarks, witnessed the rapid spread of constitutionalism and judicial review. Id., at 73. Such developments have put the Third World into a spot of bother. Evidently, the entire army of constitutionalists, pluralists, and anti-constitutionalists are constituted of European or American scholars. The focus of this article is on how the Third World has received two separate normative regimes from Europe international and constitutional law - that have proliferated due to colonisation. See Anthony Anghie, Finding the peripheries: Sovereignty and Colonialism in Nineteenth Century International Law, 40 Harv. Int'l L. J. 1(1990). 
manipulative use of zeroing methodologies under the subterfuge of the textual ambiguity of the relevant WTO norms." 170

\section{A. The Rainbow Warrior Case}

It is apt here to mention the Rainbow Warrior case between New Zealand and France that also involved separation of power issues. ${ }^{171}$ This case involved the sinking of a vessel in New Zealand waters by French agents on the direction of its government. The Chief Justice of New Zealand sentenced the two agents to life imprisonment. France negotiated their release, which New Zealand denied on the basis of "separation of power" arguments. ${ }^{172}$ New Zealand was worried about the undermining of its judiciary and it wanted the accused French agents to serve the term without interference of the New Zealand government - separation of the judiciary from the executive and legislature. It argued that working on the order of higher officials was not an excuse and that its law still considered the agents liable. Citing the Nuremburg Trials it stated that even under international law such a principle was not recognised. ${ }^{173}$

Thus New Zealand seemed to have put up a case for its monist approach to international, i.e., France needed to find other ways to secure their release. According to New Zealand law, the two French agents could not buy freedom. However, under Section 22 of the New Zealand Immigration Act 1964, they could be transferred to a prison in France. ${ }^{174}$ But under Article 327 of the French Penal Code; the agents could not serve a term in France pursuant to a New Zealand court's decision. The UN Secretary-General finally ruled for transfer to an isolated island with periodic supervision and reporting by France to New Zealand. ${ }^{175}$

The Rainbow Warrior represents the issues of constitutional conflicts in international law; sovereigns random derogate from their own constitu-

170 Cho, supra note 3, at 624, 92.

171 UN Secretary General, Ruling On the Rainbow Warrior Affair between France \& New Zealand, 26 ILM 1346 (1987).

$172 I d$. However, New Zealand later conceded that its constitution did mandate the transfer of prisoners of foreign nationality but the government was unwilling.

173 Id. at 1357.

$174 \quad I d$. at 1365

175 Id. at 1370. 
tions. India- $Q R s$ is a step further; it is not about defending its constitution like in Rainbow Warrior but taking the separation of power argument before an international court. Much before the WTO "cultivat[ed] a new hermeneutics on the WTO Antidumping Agreement, one that envisions new institutional meanings and possibilities within the WTO that resonate with its telos," 176 cases such as Rainbow Warrior must have played a norm creating role that bulldozed the constitutional roads through the power obsessed international legal structure.

\section{B. India-QRs Case: India's Constitutionalism Rejected}

The principle of institutional balance has an important role to play in the WTO context as well. ${ }^{177}$... [t] he Panel's view [refuting] the distribution of powers between the judicial and the political organs of the WTO is inconsistent with the practice under the GATT $1947 .{ }^{178}$... India disagrees ... that assigning legal functions to other WTO bodies is only relevant if there is an express provision that limits the panel's competence. Domestic courts and the ECJ have developed doctrines providing for deference by courts to political institutions without there being an explicit limitation on their competence. There is, therefore, no reason why panels and the $\mathrm{AB}$ could not do the same. ${ }^{179}$

The $\mathrm{AB}$ decided that dispute settlement panels are competent to review matters concerning balance of payments (BOP) restrictions, and rejected India's argument that a principle of institutional balance requires that matters relating to $\mathrm{BOP}$ restrictions be left to the relevant political organs - the BOP Committee and the General Council. The AB did not see any "separation of powers" envisaged by the framers of the WTO agreement. ${ }^{180}$ Notably in opposition to this view, Bogdandy explicitly talks about the separation of power within the WTO. ${ }^{181}$ His elaborately advanced thesis

\footnotetext{
176 Cho, supra note 3, at 626.

177 India-QRs, supra note 155, at 10.

$178 \quad$ Id. 911.

179 Id. 23.

180 Lorand Bartels, The Separation of Powers in the WTO: How to Avoid Judicial Activism, 53 InT'L Comp. L. Q. 861-895 (2004).

181 Bogdandy, supra note 3, at 614.
} 
warrants greater attention. Like many German scholars before him, he displays a robust liking for a constitutional view of international economic law.

He observes that the "WTO agreement reproduces the traditional conceptual distinction developed by the theory of the state with respect to the functions of public authority in a surprisingly faithful way." 182 Three sub-articles of Article III hint at the executive, legislative, and administrative functions of this international trade body. ${ }^{183}$ But this puzzles Dunoff, "neither WTO texts nor practice suggest that the WTO is a constitutional entity." 184 The disjunction between scholarship and practice, he thinks, is remarkable. He asks, "Why would scholars debate the WTO's (non-existent) constitutional features?"185

The refusal of India's arguments, in my view, stands as a burning example of the unlearning of international laws' many classic concepts by the First World. The AB's rejection of India's separation of power arguments looks all the more suspect since in Brazil-Export Finance Programme for Aircraft; a WTO Panel invoked a separation of power argument to Canada's benefit. ${ }^{186}$ Babu says that the Panel in this case ignored the special and differential treatment conditionality that ought to be read into the WTO law's interpretation. ${ }^{187}$ Instead, the Panel reasoned that the question of "development need" was a political and economic question, which the WTO's Subsidies Committee, and not the Panel should consider, given the Panel's function is fundamentally legal. ${ }^{188}$ While in India-QRs the AB rejected a developing country's constitutional separation of power argument, the Brazil-Export Panel invoked the same argument in Canada's favour. ${ }^{189}$ Furthermore, in the Kadi case the EU is unlearning monism,

\footnotetext{
$182 I d$. at 614.

183 Id.

184 Dunoff, supra note 3, at 647.

185 Id.

186 Report of the Appellate Body, Brazil-Export Finance Programme for Aircraft, WT/ DS46/AB/R. 2 Aug. 1999.

187 R. Rajesh Babu, Interpretation of the WTO Agreements, Democratic Legitimacy and Developing Nations, 50 Indian J. InT'L L. 45, 83 (2010).

188 Id.

189 Report of the Panel, Brazil - Export Financing Programme For Aircraft, 14 April 1999, WT/DS46/R, II 7.89 (“an examination as to whether export subsidies are
} 
an old doctrine within international law bolstered by Bogdandy's argument that monism-dualism as a tool to study the relationship of states to international law are no more useful. ${ }^{190}$ In India-QRs, India argued that:

[c]onstitutions of modern democracies provide for a separation of legislative, executive and judicial powers and establish systems of checks and balances designed to avoid a concentration of governmental power. In addition, a doctrine of institutional balance has been developed by the Court of Justice of the European Communities in cases involving the question whether organs of the Communities have exceeded their powers or have infringed upon the powers of the other organs. ${ }^{191}$

India is a country known for its powerful judiciary and constitution. Separation of powers is central to India's administrative routine. Her extraordinary belief in the power of constitutionalism (which comes from its colonial teachings) reflected in her arguments before the $\mathrm{AB}$ in India-QRs. In her advocacy at the AB, India tried to see the WTO as a constitution while distinguishing between the political and judicial wing of the WTO, which of course was rejected. As a common law country, the Indian approach has always been adversarial. Nonetheless Third World's constitutional advocacy - Indian advocacy is only an example - reinforces what the EU's constitutional experience erodes.

There is a reason behind this. There are now instances of non-convergence of legal systems inside the EU though and, maybe this new European dualist or pluralist approach to international law is a result of this internal non-convergence. ${ }^{192} \mathrm{EU}$ countries have a mix of common and civil law systems. This creates an internal fork in the road for EU's international advocacy. Contrarily, India has a clear adversarial approach. Existing First World constitutional scholarship seems almost like a design, or a kind of mandated writing that has decided to express itself in a limited vocabulary.

inconsistent with a developing country Member's development needs is an inquiry of a peculiarly economic and political nature, and notably ill-suited to review by a panel whose function is fundamentally legal.").

190 Bogdandy, supra note 149, at 223.

191 India-QRs, supra note 155, gg 2-10.

192 Pierre Legrand, European legal systems are not converging 45 INT'L \& CoMP. L. Q. 52 (1996). 
a. When the Third World sees the EU disrespecting international law at the cost of its constitutional law, it stands confused. Europe has to be more careful in unlearning certain doctrines.

b. The American scholars' international relations approach to international law is a dangerous trend. Their rejection of constitutionalisation of international law is an assertion of the non-legality of international law's management.

c. This unbundles the work of the Third World scholars who-as judges in the ICJ, the ITLOS, the WTO DSB, etc., or law professors in various universities - have, over the years, worked to assimilate non-European norms into the original construct to create plural norms.

Judgments like MOX Plant and Kadi disappoint the Third World because of the unlearning of constitutional norms after teaching it to the rest of the colonised world. The EU disrespects international law because the European law project, deduced from the ECJ decisions, enjoys precedence over international law and the primacy of European law is imposed as a constitutional necessity. ${ }^{193}$ It is apparent beyond doubt that the discourses of constitutionalism have been conducted without a mention of non-Western concerns. Constitutionalism, here, as a binary Euro-American discourse becomes an exercise in re-asserting Eurocentricism.

Constitutionalism is also an effort in claiming superiority over the power of norm creation in international law with first mover's advantage. ${ }^{194}$ This ongoing constitutionalism debate will now set the norm for what should be the authentic constitutional vocabulary for offering resistance. Thus the Third World has to engage in this debate, and not just ignore it, to find a worthwhile conclusion.

193 See Koskenniemi, supra note 43.

194 There are ample examples of what first mover's advantage in international law is. Žižek brings this out with poignance. See S. Žižek, The Obscenity of Human Rights: Violence as Symptom, 7, LACAN.COM (2005), available at http://www. lacan.com/zizviol.htm. 


\section{CONCLUSION}

International law is under severe attack today. ${ }^{195}$ European constitutionalism expects to travel from the "international" to the "global." 196 It seems improbable though as the baton seems to have been snatched by pluralism. ${ }^{197}$ Rosenfeld rightly says that "when the safe harbours of national identity, common history, and national patriotism loosen and wane, it seems much more unlikely that a working minimum number of points of material convergence can be achieved consistently." 198 Admittedly, thus the "world may be headed for a war among legal regimes that could culminate in an erosion of the rule of law itself." 199 Any "pluralist constitutional ordering" therefore, "will require harmonization through the spread of normative congruence that weaves together a plurality of legal regimes and world

195 For instance, states prefer to resolve cases that involve national security outside of the international legal framework. See, e.g., Cuban Liberty And Democratic Solidarity (Libertad) Act of 1996, PL 104-114, March 12, 1996, 110 Stat 785. "In the light of all of the above, the EU agrees to the suspension of the proceedings of the WTO panel. The EU reserves all rights to resume the panel procedure, or begin new proceedings, if action is taken against EU companies or individuals under Title III or Title IV of the Libertad Act or if the waivers under [Iran and Libya Sanctions Act] referred to above are not granted or are withdrawn." European Union-United States: Memorandum of Understanding Concerning The U.S. HelmsBurton Act And The U.S. Iran And Libya Sanctions Act, April 11, 1997, 36 ILM. 529.

196 See generally, James Tully, The Imperialism of Modern Constitutional Democracy, in The Paradox of Constitutionalism, 315-39 (Martin Loughlin \& Neil Walker ed., 2007).

197 Pluralism is vey desirable. Human rights on the domestic level seek to protect this. However, the same human rights, when it takes on its international avatar, manifests into the responsibility to protect where hundreds of people are bombed in the war on terror. Human rights become an "[a]libi for militarist interventions, sacralization for the tyranny of the market, ideological foundation for the fundamentalism of the politically correct." Zizek asks, "can the 'symbolic fiction' of universal rights be recuperated for the progressive politicization of actual socioeconomic relations?” See Slavoj Žižek, Against Human Rights, 34 New Left Rev. 115-131 (2005).

198 Rosenfeld, supra note 102, 423, g 4.

199 Id. at 421. 
views." ${ }^{200}$ What among the options, constitutionalism and pluralism, should be the Third Worlds' preferred approach? And suddenly Gandhi's Talisman that we, back in high school, used to skim, came as a possible silver lining in the cloud of normative confusion. Gandhi said:

I will give you a talisman. Whenever you are in doubt, or when the self becomes too much with you, apply the following test. Recall the face of the poorest and the weakest man [woman] whom you may have seen, and ask yourself, if the step you contemplate is going to be of any use to him [her]. Will s/he gain anything by it? Will it restore him [her] to a control over his [her] own life and destiny? ${ }^{201}$

Actually, Gandhi, in a sociological way, calls for an individual's standing in the cosmos. In legal terms, this concern translates into the advocacy of Klabbers, Peters, and Ulfstein about the role of individuals before international law and courts. ${ }^{202}$ This reading of an old Gandhian thought struck me also because of its "philosophical pluralism" that sits comfortably with Rosenfeld's idea of the "combination of legal and philosophical pluralism." 203

The Third World, as the representative of the destitute, the abider and the eternal listener, has to conduct a constant introspection to know which way to go. ${ }^{204}$ The problem of the lawyers is that they debate in the vocabulary of rights, obligations, and offences. International law's interaction with constitutional law has to also embrace the Gandhian Talisman of conducting an introspection keeping the poorest souls globally in their mind. This Talisman is a great way to avoid the discursive trap of legal

200 Id. at 417.

201 Gandhi International Institute for Peace, Essential Quotes of Mahatma Ghandi, available at http://www.gandhianpeace.com/quotes.html.

202 See Jan Klabbers, Anne Peters, \& Geir Ulfstein, The Constitutionalization of INTERNATIONAL LAW (2009).

203 Rosenfeld, supra note 102, at 417, 3.

204 See Prabhakar Singh, The Scandal of Enlightenment and the Birth of Disciplines: Is International Law a Science? 12 (1) Int'L Cmty. L. Rev., 5-34 (2010). A new literature has emerged that suspects human rights. See Ian Balfour \& Eduardo Cadava, The Claims of Human Rights: An Introduction, 103 (2-3) South Atrantic Q. 277-296 (2004). 
formalism. As a lens, this Talisman's ability to magnify international law's hidden injustices in its political overtures is very high.

The Third World has been a major importer of knowledge since colonisation began, and constitutional norms are its examples. ${ }^{205}$ It continues to do so. Therefore the First World has to be careful in what to offer and what not to unlearn. Today, when globalisation is unbundling a sovereign state and constitutionalism has emerged as a good tool for its re-organisation, it is high time that the constitutional lessons learned in the Third World find a role in this new re-organisation of sovereign. ${ }^{206}$ We have to wait to see whether, for the Third World, the takeover of dualism by pluralism, on account of - as Bogdandy puts it — "internationalisation of constitutional law" is better or worse. ${ }^{207}$ Constitutionalism has a co-optive potential and its ability to offer resistance and emancipate marginalized subjects within international law remain very limited.

205 See for a full scale debate, Richard Falk, Balakrishnan RaJagopal, JaCqueline Stevens, International Law and the Third World: Reshaping Justice (2008).

206 See, e.g., R.P. Anand, The Formation of International Organizations and India: A Historical Study, 23 LEIDEN J. INT'L L. 5-21 (2010).

207 Bogdandy, supra note 149, 397. 